\title{
NEW SPECIES AND COMBINATIONS IN COSTA RICAN ORCHIDS. II
}

\author{
ROBERT L. DRESSLER \\ Missouri Botanical Garden, Florida Museum of Natural History, Marie Selby Botanical Gardens \\ Mailing address: 21305 NW 86th Ave., Micanopy, Florida 32667, U.S.A.
}

\begin{abstract}
Govenia viaria, from Monteverde to the Dota area, and Palmorchis eidae, from the area of Golfito, are described and illustrated, and Dichaea elliptica, from Panama and southern Costa Rica, is described. A new combination is published for Chondroscaphe endresii, a distinct species that has been confused with C. bicolor; a broader concept of Scaphyglottis calls for the following new combinations: Scaphyglottis bidentata, S. cuniculata, and S. imbricata. The new name Pleurothallis grammata is published, based on Myoxanthus vittatus Pupulin \& M.A.Blanco.
\end{abstract}

RESUmen. Se describen e ilustran Govenia viaria, de Monteverde hasta el área de Dota, y Palmorchis eidae, del área de Golfito, y se describe Dichaea elliptica, de Panamá y del sur de Costa Rica. Se publica una nueva combinación para Chondroscaphe endresii, una especie distinta que se ha confundido con C. bicolor. Un concepto más amplio de Scaphyglottis requiere de nuevas combinaciones: Scaphyglottis bidentata, S. cuniculata y S. imbricata. Se publica el nombre nuevo Pleurothallis grammata, basado en Myoxanthus vittatus Pupulin y M.A.Blanco.

The preparation of the orchid treatment for the Manual de las Plantas de Costa Rica has brought to light a number of new species (Dressler 1995, 1997, among others). The publication of the Monocotyledon volumes is planned for the near future. The present paper will describe three unnamed species for which adequate material is at hand, and publish a few new combinations needed for the Manual.

\section{Dichaea elliptica Dressler \& Folsom, sp. nov.}

TYPE: Panama. Coclé, Aserradero El Copé, ca. 8 km N of El Copé, 800-900 m; 9, 10 April 1977; Dressler 5641 (holotype MO, isotype PMA).

Dichaeae brachypodae similis, foliis ellipticis et ovario muricato dignoscenda.

Epiphytic, erect or pendent, roots $0.5-0.8 \mathrm{~mm}$ in diameter, puberulent; stems 9-22 cm; leaves distichous, sheathing bases appressed to stem, blades 1.3-2.8 x 0.3-0.7 mm, elliptic or lanceolate-elliptic, acuminate, apices hispid-ciliate for $5-8 \mathrm{~mm}$. Inflorescence axillary, 1-flowered, peduncle 7-12 $\mathrm{mm}$; floral bract 3-5 x 3-4 mm, basally clasping, broadly ovate, carinate, acute or apiculate; ovary and pedicel $0.8-1 \mathrm{~mm}$, muricate; flowers cream speckled with red or violet; sepals 6-8 x 2.3-3.5 $\mathrm{mm}$, lanceolate, apiculate; petals $6-8 \times 1.8-2.5 \mathrm{~mm}$, elliptic-obovate to lanceolate, acute; lip 5.5-7 x 6.5$7 \mathrm{~mm}$, claw cuneate, $3.5 \times 3-4 \mathrm{~mm}$, blade lunate to subtriangular, with acute, recurved basal angles, apiculate; column stout, $2.5-3 \mathrm{~mm}$.

Other material Seen: Costa Rica. Puntarenas: Las Alturas, above las Cruces, flowered in cult. 11 Sept. 1995, J. Luer s.n. (MO). Panama. Chiriquí: Camp Hornito, Fortuna dam site, $8^{\circ} 44^{\prime} \mathrm{N} 82^{\circ} 10^{\prime} \mathrm{W}$, to Cerro Fortuna, 1200 1500 m, 16 Aug. 1976, Dressler 5399 (MO); Coclé: S. of Cascajal along continental divide, $80^{\circ} 25^{\prime} \mathrm{W}, 8^{\circ} 45^{\prime} \mathrm{N}, 7$ Nov. 1981, S. Knapp 1986 (MO); Darién: Cerro Sapo, elev. 700-900 m, 1-2 Feb. 1978, Dressler 5779 (MO); Panamá: Cerro Campana, 10 July 1968, Dressler 3535 (MO); 10 May 1969, Dressler 3627 (MO); La Eneida, 10 May 1969, Dressler 3626 (MO); 8 July 1969, Dressler 3650 (PMA); Veraguas: First branch of Río Santa María, about 8 km NW of Santa Fé, elev. ca. 650 m, 4 Aug. 1975, Dressler 5063 (MO); Proyecto Arizona (Buenos Aires), N. slope of ridge E. of Cerro Arizona, 950 m, 12 Oct. 1975, Dressler 5190 (MO, PMA); Cerro Arizona (Tute) NW of Santa Fé, 10-11 Feb. 1976, Dressler 5531 (MO).

Dichaea brachypoda Rchb.f. was based on Wendland 809 (W-R!), from San Miguel, Costa Rica. The name has been used quite widely by 
Reichenbach, himself, and was applied to $D$. camaridioides Schltr. by Dunsterville \& Garay (1965). We confidently used the name for a common species in Panama, until we looked at the type, which is a Dichaea with a smooth ovary. We have seen nothing like the type from Costa Rica. Though Wendland 809 was apparently collected in the field, its aspect is more typical of specimens prepared from cultivated plants, a scrap of vegetative material with one or two flowers. Until such a plant is (again) found in Costa Rica, we remain a bit sceptical as to its origin. Dichaea elliptica differs from $D$. camaridioides in that it has a distinct, strap-like ligule, rather than a triangular projection of the ventral margin of the stigma.

\section{Govenia viaria Dressler, $s p$. nov.}

FIG. 1.

TYPE: Costa Rica. San José, Panamerican Highway south of Cartago, about km. 46, 21 July 1994, R. L. Dressler \& D. E. Mora 6168 (holotype $\mathrm{MO}$, Isotype USJ).

Herba terrestris mediana cormis ovoideis, foliis duobus, racemo pedunculato, floribus parvis, flavis, sepalis petalisque brunneo suffusa; labelo ovato apiculato.

Terrestrial, roots $1-2 \mathrm{~mm}$ in diameter; corms ovoid, 3.5-4 x 2.5-3.5 cm; leaves 2 (-3), petioles 18$22 \mathrm{~cm}$, tubular below, blades elliptic, acute or acuminate, $25-40 \times 6.5-10 \mathrm{~cm}$, leaves basally surrounded by tubular sheaths $10-17 \mathrm{~cm}$; inflorescence lateral, peduncle $30-70 \mathrm{~cm}$, with 1-2 tubular bracts 1.5-5 cm, raceme $14-20 \mathrm{~cm}$; floral bracts linear or sublinear, acuminate, 15-20 (30) x 2-3 (4) mm; ovary and pedicel $16-20 \mathrm{~mm}$; flowers pale yellow, sepals flushed red-brown within, petals barred with red-brown within, lip basally red-brown, apically with 5 brown spots; dorsal sepal oblong-elliptic or oblanceolate-elliptic, concave, subobtuse or acute, 12-15 x 3.5-4.6 mm; lateral sepals oblong-elliptic, falcate, acute or apiculate, 9.5-10 x 3.5-5.5 mm; lip unguiculate, ovate or subquadrate-ovate, abruptly apiculate, 7 x $4 \mathrm{~mm}$; column 6-7 $\mathrm{mm}$, arcuate, column wings rounded or subtriangular, ca. $1.5 \times 2$ $\mathrm{mm}$.

This species is distinctive in its small flowers with relatively narrow parts. Though the flowers are basically yellow, this species does not appear to be a member of the G. superba complex. The anther has a subulate beak, rather than a wide, triangular beak as in G. superba and its close allies. Govenia viaria is locally common along the Interamerican highway south of Cartago, thus the epithet viaria, from Latin via, road or highway.

Other material Seen: Costa Rica, Alajuela: Palmira, alt. 5800 ft, Sept. 1937, Austin Smith 272 (AMES); Cartago: road from Cartago to Cerro de la Muerte, Aug. 1963, R. L. Dressler 2872 (FLAS); Puntarenas: Monteverde, J. T. Atwood 89-211 (SEL); San José: Cedral de Dota, 1700-2000 m, 23 July 1969, L. D. Gómez P. 2318 (F, SEL).

Palmorchis eidae Dressler, sp. nov.

FIG. 2.

TYPE: Costa Rica. Puntarenas: Cantón de Golfito, Reserva Forestal Golfo Dulce, Serranía de Golfito, sendero a San Josecito; 8 40'21"N $83^{\circ} 14^{\prime} 38^{\prime \prime} \mathrm{W}, 30 \mathrm{~m}$. Hierba creciendo en bosque primario, flores moradas; 17 oct. 1996; Eida Fletes 414 (holotype INB, Isotype MO).

Plant caespitose, ca. $20 \mathrm{~cm}$; roots $0.5-1 \mathrm{~mm}$ in diameter; vegetative stem ca. $10 \mathrm{~cm}$, covered by leaf-sheaths; sheath with petiole $3.5-4.5 \mathrm{~cm}$; blades plicate, elliptic or elliptic-lanceolate, acuminate, 4.5-12.5 x 1-2.3 cm; peduncle ca. $5 \mathrm{~cm}$, with 1 or 2 lanceolate bracts $1.5-5 \times 0.2-0.5 \mathrm{~cm}$; raceme short, flowers successive; floral bracts narrowly triangular-ovate, acute, heavily veined, ca. 4 x $1.2 \mathrm{~mm}$; flowers purple; ovary and pedicel ca. $9 \mathrm{~mm}$; sepals linear-oblanceolate, acute or apiculate, carinate, ca. 17 x $2.3 \mathrm{~mm}$; petals linear-oblanceolate, obtuse, 17 x $2 \mathrm{~mm}$; lip 3-lobed, lateral lobes connate over column, tubular, ca. $12.5 \mathrm{~mm}$, midlobe obcordate, unguiculate, $4.5 \times 7 \mathrm{~mm}$, with high keel in throat and on base of blade, ca. $0.3 \mathrm{~mm}$ high; column ca. $12 \mathrm{~mm}$.

This remarkable little Palmorchis has the lateral lobes of the lip connate over the column and the flowers are described as purple. Only a single flower is known but it is in quite good condition. I have not dared dissect it but it is clearly very distinct from all known species of Palmorchis. The species is named for the collector, Eida Fletes. Careful work in the region of Golfito and Península 


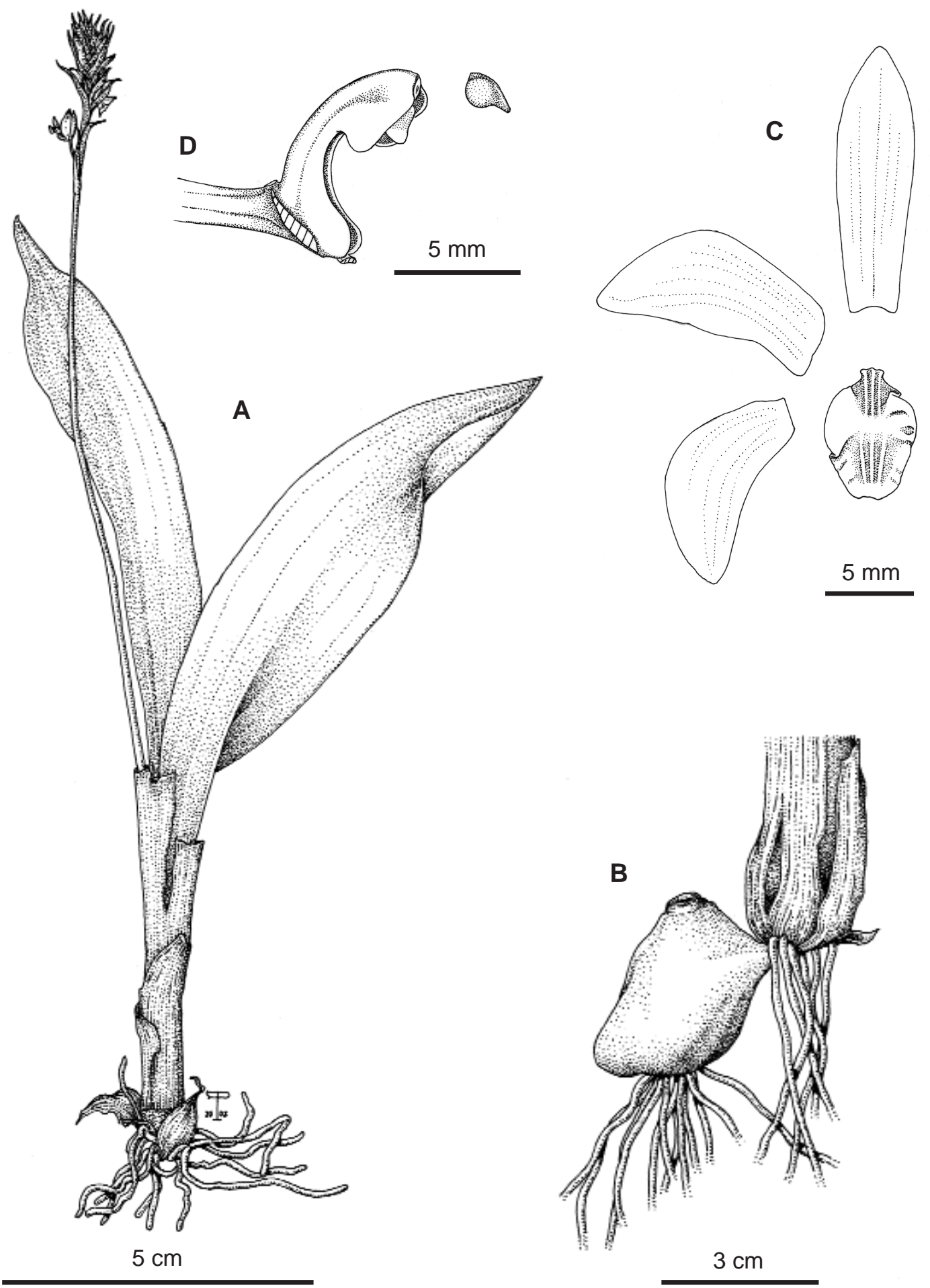

Figure 1. Govenia viaria Dressler. A - Habit. B - Corm. C - Perianth parts flattened. D - Lateral view of column and anther. Illustration voucher: Dressler \& Mora 6168 (MO and USJ). Drawn from the type. 


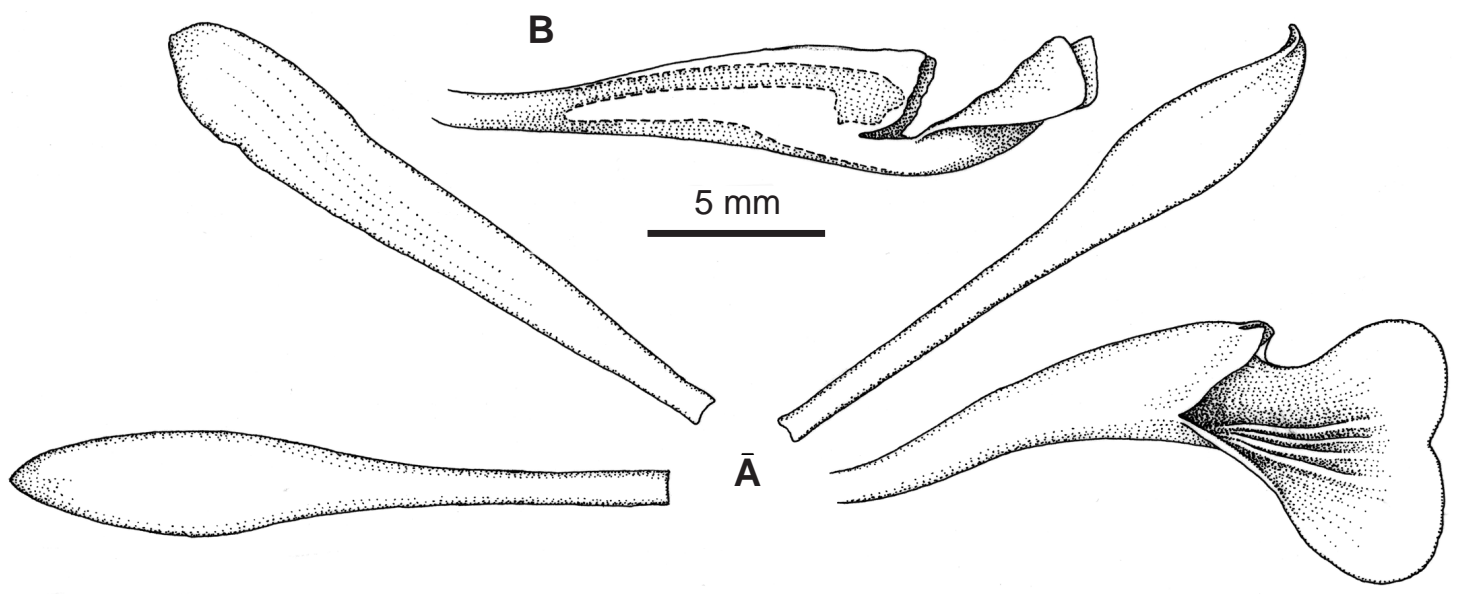

Figure 2. Palmorchis eidae Dressler. A - Perianth parts flattened. B - Lip shown from side, to show relationship between column and lip. Illustration voucher: Fletes 414 (MO). Drawn from the type.

de Osa will surely turn up other undescribed species. There is already material clearly not of any described species, but the material is too poor to permit description.

Chondroscaphe endresii (Schltr.) Dressler, comb. nov.

Basionym: Chondrorhyncha endresii Schltr., Repert. Spec. Nov. Regni Veg. 17: 14. 1921. Holotype: Costa Rica, Endres 166 (W-R!).

A molecular analysis of the Zygopetalinae is in process at the University of Florida (Whitten, Williams \& Dressler), of which preliminary results have been given in Orquideología 21: 233-255. 2000, and 22: 12-22. 2001. At that time, I had not studied the type of Chondrorhyncha bicolor Rolfe, the most commonly used name in Costa Rica, and I assumed that it was the same as C. endresii Schltr. Now, I have studied both type specimens. The type of C. bicolor is poorly preserved and does not match any species that I know from Central America. Hopefully, further collecting will permit the identification of this taxon with a known species, but, at present, I can only say "It's not that." Chondrorhyncha endresii, however, is definitely the species most often identified as C. bicolor. Thus, a new combination is needed in Chondroscaphe for C. endresii.

Pleurothallis (Sect. Selenia) grammata (Pupulin \& Blanco) Dressler, comb. nov.
Basionym: Myoxanthus vittatus Pupulin \& M.A.Blanco, Lankesteriana 2: 16. 2001.

This last-minute addition to the orchid flora of Costa Rica is clearly a member of the Section Selenia, which has been assigned to both Pleurothallis and Myoxanthus. Thus, to place it with its close allies in the Manual treatment, it is here transferred to Pleurothallis.

Scaphyglottis bidentata (Lind1.) Dressler, comb. nov.

Basionym: Hexisea bidentata Lindl., Hook. Journ. Bot. 1: 8 (1834).

Scaphyglottis cuniculata (Schltr.) Dressler, comb. nov.

Basionym: Fractiunguis cuniculatus Schltr., Repert. SP. Nov. Regni. Veg. Beih. 19: 31. 1923. TYPE: C. Wercklé 83 (B, destroyed?); Reichenbachanthus cuniculatus (Schltr.) Pabst.

Scaphyglottis imbricata (Lind1.) Dressler, comb. nov.

Basionym: Diothonaea imbricata Lindl., Sert. Orch. t. 40 (1841). Hexisea imbricata (Lindl.) Rchb.f., Walp. Ann. Bot. Syst. 6: 470 (1862).

A molecular analysis of the Scaphyglottis complex has been completed, though the paper to present these results is still in preparation. For our purposes, the most important result is that both Hexisea 
and Reichenbachanthus are embedded in one of the major clades of Scaphyglottis. thus new combinations are offered here. The other Central American species of Reichenbachanthus already have valid names in Scaphyglottis.

ACKNOWLEDGMENTS. I thank Stig Dalström for the drawings of floral details, and I thank Franco Pupulin for aid with the Latin diagnoses.
Literature Cited

Dressler, R. L. 1995. New Orchid Species from Costa Rica. Novon 5: 140-145. 1997. New Species and Combinations in Costa Rican Orchids. Novon 7: 120-126. 2000. Precursor to a revision of the Chondrorhyncha complex. Orquideología 21: 232-255. 2001. On the genus Chondroscaphe, with two new species from Central America, Chondroscaphe atrilinguis and C. laevis. Orquideología 22: 12-22.

Dunsterville, G. C. K., \& L. A. Garay. 1965. Venezuelan Orchids Illustrated, vol. 3

Romero-G., G. A., \& G. Carnevali F.-G. 2000. Orchids of Venezuela, An Illustrated Field Guide, 2nd edition. 